\title{
Daily Rhythms of Serum Vitamin D-Metabolites, Calcium and Phosphorus in Horses
}

\author{
G. PICCIONE ${ }^{1}$, A. ASSENZA ${ }^{1}$, F. FAZIO ${ }^{1}$, D. BERGERO ${ }^{2}$, G. CAOLA $^{1}$ \\ ${ }^{1}$ Department of Experimental Science and Applied Biotechnology, \\ Laboratory of Veterinary Chronophysiology, Faculty of Veterinary Medicine University of Messina, Italy \\ ${ }^{2}$ Department of Animals Productions, Epidemiology and Ecology, \\ Faculty of Veterinary Medicine, University of Torino, Italy \\ Received February 26, 2007 \\ Accepted March 13, 2008
}

\begin{abstract}
Piccione G., A. Assenza, F. Fazio, D. Bergero, G. Caola: Daily Rhythms of Serum Vitamin D-Metabolites, Calcium and Phosphorus in Horses. Acta Vet. Brno 2008, 77: 151-157.

Many physiological processes of domestic animals exhibit daily rhythmicity. The goal of the present study was to investigate the daily rhythms of calcium, inorganic phosphorus and $24,25-(\mathrm{OH})_{2}-\mathrm{D}_{3}, 25-(\mathrm{OH})-\mathrm{D}_{3}$ and $1,25-(\mathrm{OH})_{2}-\mathrm{D}_{3}$ in the blood serum of horses. Five Thoroughbred mares from the same farm, clinically healthy and placed in individual stalls, at the same environmental temperature and photoperiod were used. For 30 days prior to the study, the animals underwent the same pattern of daily activity. Blood samples were collected at 4 h-intervals for 48 consecutive $\mathrm{h}$, starting at 08:00 $\mathrm{h}$ of the first day and finishing at 04:00 $\mathrm{h}$ of the second day, via intravenous cannula inserted into the jugular vein. Each individual sample was assessed for serum concentration of calcium and inorganic phosphorus by means of a UV spectrophotometric test, and serum concentration of $24,25-(\mathrm{OH})-\mathrm{D}_{3}, 25-(\mathrm{OH})-\mathrm{D}_{3}$, and 1,25$(\mathrm{OH})_{2}-\mathrm{D}_{3}$ were assessed by means of HPLC method. Data analysis was conducted by one-way repeated measures analysis of variance (ANOVA) and by the single cosinor method. ANOVA showed a significant effect of time on all the variables studied $(p<0.0001)$ and post-hoc test (SNK) showed significant differences $(p<0.001)$ comparing all the time intervals of $4 \mathrm{~h}$, on either day. The application of the periodic model and the statistical analysis of the cosinor procedure allowed defining the periodic variables and their acrophases (expressed in hours) during the 2 days of monitoring. Calcium showed diurnal acrophases at 15:00 $\mathrm{h}$ for the $1^{\text {st }}$ day and at 15:48 for the $2^{\text {nd }}$ day; inorganic phosphorus showed diurnal coincident acrophases at $14: 32 \mathrm{~h}$ both for the $1^{\text {st }}$ and $2^{\text {nd }}$ day and $25-(\mathrm{OH})-\mathrm{D}_{3}$ showed diurnal acrophases at 14:08 $\mathrm{h}$ for the $1^{\text {st }}$ day and at 15:04 $\mathrm{h}$ for the $2^{\text {nd }}$ day. The results obtained could be useful for standardizing blood sampling according to the time of day and for optimizing the administration of these substances according to their circadian or other rhythms.
\end{abstract}

Chronophysiology, circadian mineral rhythms, diurnal 1,25-(OH) $-\mathrm{D}_{3}$ variations, Equus caballus

Rhythm is a process repeating itself on a regular basis in all animals (e. g. the cardiac cycle, respiratory cycle). In physiology terms, chronobiology provides generally applicable concepts and techniques for resolving predictable cycles in organism and for isolating environmental effects from the underlying endogenous mechanisms. Daily oscillation in biochemical, haematological and physiological variables has been described in a variety of species (Johnson et al. 2004; Refinetti 2006) and rhythmic events have been verified in different ranges of frequency in livestock (Piccione and Caola 2002) and, particularly, in horses (Piccione et al. 2001, 2002, 2004bc, 2005ab). Many metabolic aspects are assessed in different productive and physiological conditions based on their rhythmic variations. The knowledge of rhythmicity as an intrinsic component of the living matter led us to redefine some important physiological concepts, such as homeostasis, and to study physiological rhythms and their modifications also from a diagnostic viewpoint, in order to show diseases 
not clinically evident. For the normal vital process, minerals play an essential role and among inorganic substances, calcium and inorganic phosphorus are the most abundant minerals (among 70 and $95 \%$ in the body) and vitamin D plays a key role in regulating their homeostasis. However, in horses, this homeostatic system differs in many aspects from that of most mammalian species and it is still unknown what mechanisms are responsible for their control in the equine blood serum (Mäenpää et al. 1988; Breidenbach et al. 1998; Harmeyer et al. 2004). Since the presence of daily rhythms in the blood serum concentration of calcium and phosphorus, well established in humans, may have significant physiological effects, the aim of the present study was to determine the daily rhythmicity in the blood serum of calcium, inorganic phosphorus and $24,25-(\mathrm{OH})_{2}-\mathrm{D}_{3}, 25-(\mathrm{OH})-\mathrm{D}_{3}$ and $1,25-(\mathrm{OH})_{2}-\mathrm{D}_{3}$ in horses.

\section{Materials and Methods}

Five Thoroughbred mares, 8 years old, weighing $430 \pm 20 \mathrm{~kg}$, clinically healthy were used. For 30 days prior to the study, the animals underwent the same pattern of daily activity. They were housed in individual stalls $(3.5 \times 3.5 \mathrm{~m})$, under a natural photoperiod (sunrise at 07:00 h, sunset at 17:30 h) and natural indoor temperature $\left(17-19^{\circ} \mathrm{C}\right)$ and fed twice a day with $2 \mathrm{~kg}$ concentrates and $3 \mathrm{~kg}$ hay at 12:00 $\mathrm{h}$ and $3 \mathrm{~kg}$ concentrates plus 4 to $5 \mathrm{~kg}$ hay at 17:00 h. Ca and total $\mathrm{P}$ content were measured in the feedstuffs offered by means of titration and spectrophotometry, respectively, according to GU CE L 155/16 of July 12, 1971.

Blood samples were collected at 4-h intervals over a 48-h period (starting at 08:00 h on day 1 and finishing at 04:00 on day 2) via an intravenous cannula inserted into the jugular vein. Blood samples clotted at room temperature for $1 \mathrm{~h}$. Samples were centrifuged at $3000 \times \mathrm{g}$ for $10 \mathrm{~min}$ and sera stored at $-40{ }^{\circ} \mathrm{C}$ until being assayed for variables. Each individual sample was assessed for serum concentration of calcium and inorganic phosphorous by means of a UV spectrophotometer (model DU-40, Beckman Instruments, Fullerton, CA). Calcium and inorganic phosphorus was determined by means of enzymatic colorimetric test, methylthymolblue colorimetric method (Vurek 1981) and colorimetric determination with the monoreagent, (Tietz 1983), respectively. Serum concentrations of 24,25-(OH) $-\mathrm{D}_{3}, 25-(\mathrm{OH})-\mathrm{D}_{3}$ and 1,25-(OH)-D were measured by high performance liquid chromatography (HPLC - Agilent 1100, BIO-RAD) using a method based on the integration of three subsystems: continuous clean-up/pre-concentration, HPL separation and post-column fluorimetric derivatisation (Ortiz et al. 1999).

All the results were expressed as mean \pm SEM. Data were normally distributed $(p<0.05$ Kolmogorov-Smirnov test) and one-way repeated measures analysis of variance (ANOVA) was used to determine significant differences. $P$ values $<0.05$ were considered significant. SNK (Statistical Newman-Keuls) test was applied for post-hoc comparison. The acrophase of the rhythm (i.e., the time associated with the daily peak) was calculated by the fitting of a cosine wave to each daily segment of the rhythm. A family of cosine waves was generated by the equation $Y t=A+M-\cos (\theta t+\varphi)$; where M (Midline Estimating Statistic of Rhythm) is the mesor (mean level) of the rhythm segment, A is the amplitude (half the range of excursion), $\theta \mathrm{t}$ is the trigonometric angle (in degrees) corresponding to time $\mathrm{t}$, and $\varphi$ is the angle displacement for the acrophase. The values of $\mathrm{M}$ and $\mathrm{A}$ were taken from the actual records of each animal, and $\theta \mathrm{t}+\varphi$ was systematically varied from 0 to $360^{\circ}$, corresponding to $0-24 \mathrm{~h}$.

\section{Results}

The daily $\mathrm{Ca}$ and total $\mathrm{P}$ intake, according to the individual feeding plan, ranged from $35 \mathrm{~g} \mathrm{Ca}-27 \mathrm{~g} \mathrm{P}(3.5 \mathrm{~g} / \mathrm{kg} \mathrm{Ca}-2.6 \mathrm{~g}$ total P/kg dry matter) to $40 \mathrm{~g} \mathrm{Ca}-29 \mathrm{~g} \mathrm{P}(3.5 \mathrm{~g} / \mathrm{kg}$ $\mathrm{Ca}-2.5 \mathrm{~g}$ total $\mathrm{P} / \mathrm{kg}$ dry matter).

ANOVA showed a significant effect of time on all indicators studied (Table 1), on either day, as follows: calcium $\mathrm{F}_{(11,44)}=28.86, p<0.0001$; inorganic phosphorus $\mathrm{F}_{(11.44)}=$ $17.70, p<0.0001 ; 24,25-(\mathrm{OH})_{2}-\mathrm{D}_{3}^{(11,44)} \mathrm{F}_{(11,44)}=2.168, p<0.03 ; 25-(\mathrm{OH})-\mathrm{D}_{3} \mathrm{~F}_{(11,44)}=22.97$, $p<0.0001 ; 1,25-(\mathrm{OH})_{2}-\mathrm{D}_{3} \mathrm{~F}_{(11,44)}=144^{\prime} .2, p<0.0001$. The post hoc multiple comparison SNK showed significant differences $(p<0.001)$ comparing all the time intervals of $4 \mathrm{~h}$. The application of the periodic model and the statistical analysis of the cosinor procedure allowed defining the periodic parameters and their acrophases (expressed in $\mathrm{h}$ ) during the 2 days of monitoring (Table 1). Calcium showed diurnal acrophases at 15:00 h (09:28 $20: 32)$ for the $1^{\text {st }}$ day and at 15:48 h (13:08 - 18:28) for the $2^{\text {nd }}$ day; inorganic phosphorus showed diurnal coincident acrophases at $14: 32 \mathrm{~h}$ both for the $1^{\text {st }}$ and $2^{\text {nd }}$ day; $25-(\mathrm{OH})-\mathrm{D}_{3}$ showed diurnal acrophases at 14:08 $\mathrm{h}(13: 00-15: 16)$ for the $1^{\text {st }}$ day and at 15:04 $\mathrm{h}(12: 00$ 
Table 1. Values of calcium, inorganic phosphorus and metabolites of vitamin $\mathrm{D}_{3}$ in 5 thoroughbred mares

\begin{tabular}{|c|c|c|c|c|c|c|c|}
\hline Variable & Day & Mean & SEM & $\mathrm{F}_{(11,44)}$ & $p$ & $\Phi$ & A \\
\hline \multirow{2}{*}{ Calcium (mmo/l) } & 1 & 2.53 & 0.05 & \multirow{2}{*}{28.86} & \multirow{2}{*}{$<0.0001$} & $15: 00$ & 0.28 \\
\hline & 2 & 2.61 & 0.04 & & & $15: 48$ & 0.26 \\
\hline \multirow{2}{*}{ Inorganic Phosphorus (mmol/l) } & 1 & 0.84 & 0.04 & \multirow{2}{*}{17.70} & \multirow{2}{*}{$<0.0001$} & $14: 32$ & 0.20 \\
\hline & 2 & 1.01 & 0.05 & & & $14: 32$ & 0.20 \\
\hline \multirow{2}{*}{$25-(\mathrm{OH})-\mathrm{D}_{3}(\mathrm{nmol} / \mathrm{l})$} & 1 & 14.90 & 0.44 & \multirow{2}{*}{22.97} & \multirow{2}{*}{$<0.0001$} & $14: 08$ & 1.22 \\
\hline & 2 & 14.50 & 0.45 & & & 15:04 & 1.23 \\
\hline \multirow{2}{*}{$24,25-(\mathrm{OH})_{2}-\mathrm{D}_{3}(\mathrm{nmol} / 1)$} & 1 & 7.57 & 0.08 & \multirow{2}{*}{2.17} & \multirow{2}{*}{$<0.03$} & N.P. & N.P. \\
\hline & 2 & 7.59 & 0.08 & & & N.P. & N.P. \\
\hline \multirow{2}{*}{$1,25-(\mathrm{OH})_{2}-\mathrm{D}_{3}(\mathrm{pmol} / \mathrm{l})$} & 1 & 46.84 & 1.76 & \multirow{2}{*}{144.2} & \multirow{2}{*}{$<0.0001$} & N.P. & N.P. \\
\hline & 2 & 46.69 & 1.69 & & & N.P. & N.P. \\
\hline
\end{tabular}

Legend:

SEM: Standard error of the mean, F: Fisher index, $\Phi$ : Acrophase, $p$ : Statistical difference

A: Amplitude, N.P.: Non Periodic parameter

- 18:08) for the $2^{\text {nd }}$ day. The results obtained during the experimental period indicate the existence of a daily rhythm of calcium, inorganic phosphorus and $25-(\mathrm{OH})-\mathrm{D}_{3}$, as shown in Fig. 1.

\section{Discussion}

In our study calcium and inorganic phosphorus values were within the physiological range for the horse (Kaneko 1997); according to data, 24,25-(OH) $-\mathrm{D}_{3}, 25-(\mathrm{OH})-\mathrm{D}_{3}$ and 1,25-(OH $)_{2}-\mathrm{D}_{3}$ values are found by other authors in this species (Mäenpää et al. 1988; Harmeyer and Schlumbohm 2004). As shown in previous studies, serum concentrations of calcium and phosphorus are variables whose rhythmicity has a different period (from circadian to circannual), in almost all domestic animals (Pic cione et al. 2002). Particularly horses show a circasemidian rhythm of inorganic phosphorus (Piccione et al. 1996a) and a circannual rhythm of both inorganic phosphorus and calcium (Piccione et al. 1996b).

The present study confirms the existence of a circadian rhythm of both variables in horses such as in domestic animals (Piccione et al. 2004a; Wong and Klein 1984) and in humans (Markowitz 1994; Trotti et al. 2003). As for vitamin D in its three known forms: $24,25-(\mathrm{OH})_{2}-\mathrm{D}_{3}, 25-(\mathrm{OH})-\mathrm{D}_{3}$ and $1,25-(\mathrm{OH})_{2}-\mathrm{D}_{3}$, there are no relevant investigations on their rhythmic patterns, except for small diurnal variations of $1,25-(\mathrm{OH})_{2}-\mathrm{D}_{3}$ in humans (Halloran et al. 1985; Markowitz et al. 1985). Previous studies on circadian rhythms of liposoluble vitamins in horses showed the presence of a rhythmicity of liposoluble vitamins and, for vitamin $\mathrm{D}$, the presence of a circadian rhythmicity of 25-(OH)- $\mathrm{D}_{3}$ (Piccione et al. 2004b), as shown in the present study.

Calcium and inorganic phosphorus represent $70 \%$ of the organism's total content of minerals (Harrison 1998); their biological functions are well known, nevertheless, in horses, their homeostatic regulation is not yet clear (Breidenbach et al. 1998), neither has particular attention been paid to their blood rhythmic fluctuations, with the exception of the osseous tissue. A study on foals and horses showed a circadian rhythmicity of the serum osteocalcin in adults, with the peak during the night and the first hours of the day and the batiphase at noon (Black et al. 1999). If osteocalcin levels reflect the mineralization of bones and such phenomenon is at its maximum when calcium level is at its minimum (Markowitz 1994), it is interesting to notice 



Fig. 1. Daily rhythms of calcium, inorganic phosphorus and 25-(OH)- $\mathrm{D}_{3}$ in horses. Each point represents the mean $( \pm$ SEM $)(n=5)$ of calcium, inorganic phosphorus and $25-(\mathrm{OH})-\mathrm{D}_{3}$. Grey bar indicates the dark phase of the $48 \mathrm{~h}$ LD cycle. Arrowheads indicate the acrophases. 
that, in the present study, the acrophases of this indicator were recorded at 15:00 $\mathrm{h}$ during the first day and at 15:48 $\mathrm{h}$ on the second one. In humans, in contrast with calcium rhythms, those regarding inorganic phosphorus present an opposite acrophase, although this is not always true (Markowitz 1994).

Two major sources contribute to changes in the blood concentrations of minerals observed over time: newly absorbed minerals from the intestine and redistribution from endogenous stores. The relative contribution of bone and intestine as a source of variations in mineral levels appears species-specific (Markowitz 1994) and no studies in this regard have been reported in horses. The daily rhythms of inorganic phosphorus in horses in our work are thus preliminary data. The role of vitamin D in the calcium homeostasis is well known in humans, while it is uncertain in horses (Mäenpää et al. 1988; Breidenbach et al. 1998; Harmeyer and Schlumbohm 2004). Again, in this study a circadian rhythmicity was shown with acrophases always during the first hours of the afternoon, for 25-(OH)- $\mathrm{D}_{3}$ that represents the way of metabolism of vitamin $\mathrm{D}$ of endogenous origin by the liver and is, at least in humans, the main form of circulating vitamin D in the blood (Arienti 1996).

For all the studied variables, acrophases were recorded after the first and before the second meal; for this reason, meal timing seems not to be an external synchronization factor. This assumption will be controlled in further studies using different meal times. The rhythmic phenomena assessed in the present study for calcium, inorganic phosphorus and $25-(\mathrm{OH})-\mathrm{D}_{3}$ are the result of complex metabolic balance functionally not well interpreted. In fact, not all synchronizers, mainly relative to the photoperiod, rest/activity alternation, and the feeding in a quali-quantitative way, were detected. As for calcium and inorganic phosphorus, alongside the intestinal absorption rhythms, also urinary excretion rhythmicity, hormonal control, and bones remoulding processes are variables that have to be considered also from a temporal aspect. Key biological indicators, such as calcium and inorganic phosphorus, are physiologically important because their alterations are related to invalidating orthopaedic diseases (ranging from dyschondroplasias to dissecant osteochondrosis) (Savage et al. 1993), and to syndromes of performance decrease in athletic horses (Harrison 1998). Therefore, further physiological and chronophysiological investigations are needed. As for $25-(\mathrm{OH})-\mathrm{D}_{3}$, it would be interesting to better define the metabolic rhythm of hepatic production based on the daily liver activity, the diet, and the time of the day when food is available.

It is thus possible to state that although the physiological importance of mineral rhythmicity is not yet understood, the knowledge of calcium, inorganic phosphorus and 25-(OH)-D rhythmicity, their influence on other metabolic processes, their metabolism regulation and their temporal physiological values are clinically useful for the implications on some orthopaedic diseases in foals and horses, in the timing of therapeutic and nutritional protocols and for standardizing blood sampling according to the time of day.

\section{Cirkadiánní rytmus sérových metabolitů vitamínu D, vápníku a fosforu u koní}

Mnoho fyziologických procesů u domestikovaných zvírat je cirkadiánní povahy. Cílem této studie bylo zjistit jak se v průběhu dne mění koncentrace vápníku, anorganického fosforu, 24,25-(OH) $-\mathrm{D}_{3}, 25-(\mathrm{OH})-\mathrm{D}_{3}$ a 1,25- $(\mathrm{OH})_{2}-\mathrm{D}_{3} \mathrm{v}$ séru koní. Do studie bylo zahrnuto pět plnokrevných koní, pocházejících ze stejné farmy, klinicky zdravých, ustájených v samostatných boxech při stejné teplotě prostředí. Třicet dní před studií byla zvírata ve stejné zátěži. Vzorky krve byly odebírány pomocí intravenózní kanyly zavedené do v. jugularis ve čtyř hodinových intervalech 48 po sobě následujících hodin, se začátkem v 08:00 hod prvního dne a ukončením ve 04:00 h následujícího dne. U každého vzorku byla pomocí UV 
spektrofotometrie zjištěna koncentrace vápníku a anorganického fosforu v séru, koncentrace $24,25-(\mathrm{OH})-\mathrm{D}_{3}, 25-(\mathrm{OH})-\mathrm{D}_{3}$, a 1,25- $(\mathrm{OH})_{2}-\mathrm{D}_{3}$ byla stanovena prostřednictvím metody HPLC. Analýza dat byla provedena s využitím jednocestné analýzy variance (ANOVA) a metody cosinor. ANOVA ukázala významný vliv času na všechny studované ukazatele (p $<0,0001)$ a post-hoc SNK test ukázal statisticky významné rozdíly $(\mathrm{p}<0,001)$ v rámci srovnání 4 hodinových intervalů u obou dnů. Aplikace periodického modelu a statistická analýza cosinor metodou dovolila definovat periodické parametry a jejich akrofáze (stanovené v hodinách) během dvoudenního monitoringu. Pro vápník byla diurnální akrofáze v 15:00 první den a v 15:48 druhý den, u anorganického fosforu byla diurnální akrofáze oba dva dny v 14:32 a pro 25-(OH)-D byla první den v 14:08 a druhý den v 15:04. Získané výsledky by mohly být užitečné pro standardizování doby odběru krve během dne a optimalizaci v podávání těchto látek v závislosti na jejich cirkadiánních a jiných rytmech.

\section{References}

ARIENTI G 1996: Vitamina D. In: ARIENTI G (Ed.): Le basi molecolari della nutrizione. Piccin, Padova, pp. 477-484

BLACK A, SCHOKNECHT PA, RALSTON SL, SHAPSES SA 1999: Diurnal variation and age differences in the biochemical markers of bone turnover in horses. J Anim Sci 77: 75-83

BREIDENBACH A, SCHLUMBOHM C, HARMEYER J 1998: Peculiarities of vitamin D and of the calcium and phosphate homeostatic system in horses. Vet Res 29: 173-186

HALLORAN BP, PORTALE AA, CASTRO M, MORRIS RC, GOLDSMITH RS 1985: Serum concentration of 1,25-Dihydroxyvitamin D in the human: diurnal variation. J Clin Endocrinol Metab 60: 1104-1110

HARMEYER J, SCHLUMBOHM C 2004: Effects of pharmacological doses of Vitamin $\mathrm{D}_{3}$ on mineral balance and profiles of plasma Vitamin $D_{3}$ metabolites in horses. J Steroid Biochem Mol Biol 89-90: 595-600

HARRISON G 1998: Calcium and the performance horse. Horse Feed Facts 3: 17-18

JOHNSON CH, ELLIOTT J, FOSTER R 2004: Fundamental properties of circadian rhythms. In: DUNLAP JC, LOROS JJ, DECOURSEY PJ (Eds.): Chronobiology Biological Timekeeping. Sinauer Associates, Inc. Publisher, Sunderland, Massachusetts USA, pp. 67-106

KANEKO JJ, HARVEY JW, BRUSS ML 1997: Appendixes (Appendix VIII. Blood reference values in large animals). In: KANEKO JJ, HARVEY JW, BRUSS ML (Eds.): Clinical Biochemistry of Domestic Animals. $5^{\text {th }}$ ed. Academic Press, San Diego, pp. 885-897

MÄENPÄÄ PH, KOSKINEN T, KOSKINEN E 1988: Serum profiles of vitamins A, E and D in mares and foals during different seasons. J Anim Sci 66: 1418-1423

MARKOWITZ ME, ROSEN JF, MIZRUCHI M 1985: Effects of 1,25-dihydroxyvitamin $\mathrm{D}_{3}$ administration on circadian mineral rhythms in humans. Calcif Tissue Int 37: 351-356

MARKOWITZ ME 1994: Rhythms in biochemical variables related to bone and their regulating hormones. In: TOUITOU Y, HAUS E (Eds.): Biologic rhythms in clinical and laboratory medicine. Springer-Verlag, Berlin, Heidelberg, New York, pp. 179-187

NELSON W, TONG YL, LEE JK, HALBERG F 1979: Methods for Cosinor-rhythmometry. Chronobiologia 6: 305-323

ORTIZ BOYER F, FERNANDEZ ROMERO JM, LUQUE DE CASTRO MD, QUESADA JM 1999: Determination of vitamin D3 hydroxymetabolites in plasma at the sub-part per trillion levels using on-line cleanup/preconcentration and HPLC-fluorimetric post-column derivatisation. Talanta 50: 57-66

PICCIONE G, ASSENZA A, GIOFRÈ F, CAOLA G 1996a: Andamento circannuale di alcuni metaboliti azotati, della glicemia e di calcio e fosforo in cavalli di razza Murgese. Atti Soc It Ippol 13: 61-68

PICCIONE G, ASSENZA A, SCRIBANO P, CAOLA G 1996b: Organizzazione temporale circasemidiana di alcuni parametri ematochimici, ematologici e della temperatura rettale e cutanea nel cavallo purosangue inglese. Atti A S Sa V 3: 17-23

PICCIONE G, ASSENZA A, FAZIO F, GIUDICE E, CAOLA G 2001: Different periodicities of some haematological parameters in exercise-loaded athletic horses and sedentary horses. J Equine Vet Sci 12: $17-23$

PICCIONE G, CAOLA G 2002: Biological rhythm in livestock: a review. J Vet Sci 3: 145-157

PICCIONE G, CAOLA G, REFINETTI R 2002: The circadian rhythm of body temperature of the horse. Biol Rhythm Res 33: 113-119

PICCIONE G, COSTA A, GIUDICE E 2004a: Chronobiological aspect of calcium and phosphorus metabolism in dog: Clinical-therapeutic implications. Arch Vet It 55: 67-73

PICCIONE G, ASSENZA A, GRASSO F, CAOLA G 2004b: Daily rhythm of circulating fat soluble vitamin concentration (A, D, E and K) in the horse. J Circad Rhythms 2: 1-4

PICCIONE G, BERTOLUCCI C, FOÀ A, CAOLA G 2004c: Influence of fasting and exercise on the daily rhythm of serum leptin in the horse. Chronobiol Int 21:405-417 
PICCIONE G, ASSENZA A, FAZIO F, PERCIPALLE M, CAOLA G 2005a: Central fatigue and nycthemeral change of serum tryptophan and serotonin in the athletic horse. J Circad Rhythms 3: 6

PICCIONE G, PERCIPALLE M, FAZIO F, FERRANTELLI V, CAOLA G 2005b: Circadian variation of blood clotting time and circulating vitamin $\mathrm{k}$ in the athletic horse. Comp Clin Path 14: 86-89

REFINETTI R 2006: Pet selection and Veterinary Medicine. In REFINETTI R (Ed.): Circadian Physiology. $2^{\text {nd }}$ ed. Taylor \& Francis, Boca Rota, London, New York, pp. 617-629

SAVAGE CJ, McCARTHY RN, JEFFCOTT LB 1993: Effects of dietary phosphorus on induction of dyschondroplasia in foals. Equine Vet J 16: 80-83

TIETZ NW 1983: Clinical guide to laboratory tests. WB Saunders Company, Philadelphia, pp. 384-385

TROTTI R, RONDANELLI M, CUZZONI G, MAGNANI B, GABANTI E, FERRARI E 2003: Circadian organization of serum electrolytes in physiological aging. Funct Neurol 18: 77-81

VUREK GG1981: Calcium measurement: picomole quantitation by continuous-flow colorimetry. Anal Biochem 114: 288-93

WONG KM, KLEIN L 1984: Circadian variations in contributions of bone and intestine to plasma calcium in dogs. Am J Physiol-Regul Integr Comp Physiol 246: R688-R692 
